\title{
The Professional Training Motives of Ukrainian Students on Specialty "Tourism" At Technical University: Gender Index
}

\author{
Lyubchuk O., Kocharian A., Barinova N., Lunov V., Koval I., Onufriieva L., Koval A.
}

\begin{abstract}
In the article the problem of quality of preparation of specialists on tourism in the context of higher education. Found that the problem of the quality of training of specialists in tourism, hotel, and restaurant business in numerous studies abroad suggests mandatory inclusion into the educational process use of different curricula, the formation of motivation of learning, considering the requirements of employers. Many studies have revealed the motives of students of various countries to encourage them to study on the programmed for hospitality and tourism. Most of the foreign studies have found out what motivates students to choose and study in the hotel business and tourism program. In foreign studies, the influence of gender features and the course of students' professional training on the differences in the motivation of training for Scientific and Technological Progress were also studied. Study of the motivation of studying in foreign studies is aimed at studying the motives and advantages of students from different countries, who have chosen to study the program scientific and technological revolution and Scientific and Technological Progress.
\end{abstract}

We studied the importance of the motives "educational and cognitive", "professional", "working”, "obtaining a diploma", "prestige of the university", "approval of others", "legal aspects", "material support" for students of the specialty "Tourism". It confirmed that the motives of educational and professional activity of students of the specialty "Tourism" are related to the success of specialized disciplines. Statistically significant gender differences were identified in the success of the training of junior high school students in practice and in all the specialized disciplines studied. It is shown that the most significant motives of professional training for Ukrainian students of the specialty "Tourism" are the motive "working", "professional" motives and the motive "obtaining a diploma". Studying the gender differences of students in motivation for studying in the field showed that the motive of "material supply" and "professional" motives are significant for Ukrainian men, and the motives for "obtaining a diploma" and "Prestige of Higher Educational Institutions" are significant for Ukrainian women.

Revised Manuscript Received on November 15, 2019

* Correspondence Author

Lyubchuk, O.K., Professor, DPA, PhD., Head of Department of tourism, State Higher Educational Institution "Pryazovskyi State Technical University", Mariupol, Ukraine

Kocharyan A. S., Doctor of Psychological Sciences, Professor. V. N. Karazin Kharkiv National University, Head of the Department of Psychological Counseling and Psychotherapy. Ukraine.

Barinova N.V., PhD., Department of Psychological Counseling and Psychotherapy, V.N. Karazin Kharkiv National University, Kharkiv, Ukraine

Lunov V.Ye**, PhD., Professor (Associate), Bogomolets National Medical University, Ukraine. lunyov vitaliy@ukr.net

Koval I.A., PhD., MD, Professor (Associate), Bogomolets National Medical University, Ukraine.

Onufriieva L., PhD., Professor (Associate), Kamianets-Podilskyi National Ivan Ohiienko University, Kamianets-Podilskyi, Ukraine

Koval A.Sh., PhD., Associate Professor of Department of Social and Applied Psychology, Odessa I.I.Mechnikov National University, Ukraine
Keywords : gender; professional training; tourism specialists; I-concept; motivation training.

\section{INTRODUCTION}

The current state development of tourism industry is accompanied by the activation of entrepreneurial activity in the field of tourism, the change in the needs tourists, involves the study of global trends in changes in the tourism industry. Today's tourism industry is one of the world's largest revenue streams. Tourism for the present is one of the most promising directions for the development of a market economy in Ukraine. In conditions of increasing competition, the requirements on the labor market for the personality of specialists in the field of tourism are growing. Therefore, studying the motivation of students of the specialty "Tourism" is relevant for solving the problem of the quality their professional training. The current stage of development of the service sector is characterized by studies of the peculiarities of the system of training specialists in tourism in Europe (A.Korniyaka, T.Golikova 2013; L.Knodel, 2007), a description of teaching methods and training in the Netherlands (B. Brunets, 2012), analysis the experience of training specialists for tourism in the example of individual educational institutions in the Americas (V. Fedorchenko, 2004). It believed that Switzerland is the first country in the world to create a model of higher education in the hotel business, its hotel and tourism schools are considered to be benchmarks. The Lausanne School requires from its students real motivation and other manifestations of personality $(\mathrm{G}$ Harbar, 2018). The high quality of training specialists in tourism, hotel and restaurant business abroad is ensured by the presence of practice as a compulsory component of the educational process, the close merger of training tasks with leading enterprises, the use of various training programs, the formation of internal firm motivation.

In Ukraine, the concept of "quality" of professional education in theoretical studies has ambiguous understanding. The quality of education is revealed as the formation of knowledge, skills and abilities, the experience of creative activity, values (O. Lebedev, 2007) as a measure of achievement of goals (D.Matros, 2001), ensuring the competitiveness of graduates of higher education in the labor market (V.Shinkaruk, 2007), the orientation of education to state standards (O.Babkina, 2006), compliance with the requirements and expectations of society (O. Burego, 2009). 
Achievements in education in Ukraine are still evaluated by internal criteria such as: academic success and participation in Olympiads (A.Mazak, 2005). For Ukraine, a transitional stage in the development of post-industrial production is characteristic, which is marked by the formation of a mass of higher education, a decrease in its quality and high status in society. The main contradictions of the traditional education model are the following: the success of the learner, as well the quality of education, are determined by "success" (a good learning of someone else's knowledge); the mechanism of "explanation-assimilation" interferes with the development of independent, creative thinking, motivation to study, psychological potential of a specialist. One of the main problems of professional training is the identification of conditions that would contribute to the formation of students of psychological potential, in particular, the educational and professional motivation (O. Lyubchuk, 2012), "I-concepts" (O. Lyubchuk, 2005), values of professional self-realization (N Antonova, 2001). The problem of motivation of studying students from different countries in the field of hotel business and tourism was the subject of several studies.

The study (Myong Jae Lee, David A. Olds, Chang Lee, 2008) found out what motivates US students to study for the hospitality and tourism management program. The specificity of this study was to study the impact of gender characteristics and the course of professional training on the differences in the motivation of studying for Scientific and Technological Progress (hospitality and tourism management). Also defined are subject areas in the Scientific and Technological Progress in which American students want to specialize. This study showed that the motives for learning were: "self-actualization", "ability to work", and "attractiveness of the sphere of activity", "foreign experience", "external influence and ease of training". The dominant motivators are "ability to work" and "self-actualization".

The relationship between the different types of student motivation in Portugal was studied in the study (Francisco Cesário, Miguel Portugal, Bruno Rodrigues, Antónia Correia, 2017), which focused on the problem of motivating the search for work in the field of hotel business and tourism and adherence to these courses. The results showed that for a career in the hotel business and tourism for Portuguese students, motivation is important as a correspondence to personal values and lifestyle, interesting work, receive incentives. Students with intriguing motivation show a positive and significant commitment of the university. The work (Bashar Aref Alhaj Mohammad, Hamam Talal Alsaleh, 2013) explored the motivation of the students in Jordan to study the Hospitality Tourism Program. The research was aimed at identifying the motives for studying the Jordanian tourism program and their gender characteristics. It was found that social status was the most important motive for studying the program of hospitality management and tourism, as well as getting work in any tourist organization, such as classified hotels, handicrafts shops or tourist guides.

The study (Appaw-Agbola Esther Theresa, George Kwadzo Agbotse, 2013) focused on exploring the motives and benefits of the students in Ghana who chose to study the found that students are given the advantages of the motive of employment, which parents are influenced by, attempts to self-actualization, scholastic achievements, the attractiveness of the sphere of activity, and the ease of learning. The problem Scientific and Technological Progress program. It has been

of mismatching student expectations and tourism management in Ghana with regard to improving the quality of tourism services based on the demonstration of entrepreneurial skills has been identified. The tendency of student's orientation on the motivation of employment in the field of hotel services and tourism, and not on the creation of their own enterprises. The Seongseop (Sam) Kim, Jishim Jung, Kuo-Ching Wang, 2016 study on the comparison of the preferences of students from three Asian regional groups in hospitality and tourism careers. This study showed that Korean students prefer to work in the aviation industry, the hotel industry and travel agencies after graduating from the Scientific and Technological Progress program. Taiwanese students prefer to work in the hotel and restaurant industry. Hong Kong students see privileges in aviation industry and event management. The study found that students are most interested in acquiring practical knowledge, besides the problem of employment. Qualitative education involves providing both effective lectures and counseling services as a popular resource that meets real needs. Thus, studying the motivation of studying in foreign studies is aimed at studying the motives and benefits of students from different countries, who have chosen their gender characteristics to study the scientific and technological revolution and Scientific and Technological Progress program.

The object of the research is the motivation of the university students studying the specialty "Tourism".

The subject of the research is the influence of educational and professional motives on the success of students' professional training, their gender characteristics.

Thus, under the motive of educational activity, understand all the factors that determine the manifestation of learning activity, in particular, needs, goals, guidelines, and sense of duty, interests, and others. In the structure of educational-professional motifs distinguish internal motifs that include the motive of their own development in the learning process, the motive of learning new. External educational and professional motives are manifested as a motive of forced learning, the motive of learning as a routine operation, the motive of teaching for leadership and prestige, the motive of material reward, the motive for avoiding failures. Motives, even the most positive, create only a potential opportunity for the development of students. The implementation of motives depends on the person's ability to set goals and achieve them in the learning process. The main factors influencing the formation of positive motivation for educational activities include the content of educational disciplines, the organization of the learning process, the style of teaching, the presence of a positive "I-concept", the correspondence with the expectations of students and others.

\section{MATERIALS AND METHODS}

In the empirical study involved 43 students of the specialty "Tourism" of the first and second courses of full-time training at the "Pryazovskyi State Technical University" city of Mariupol (Ukraine). The following methodology "Researching the motives of educational activity of students" was used (Lyubchuk, 2012). 
Methods of empirical processing and data interpretation: quantitative and qualitative analysis (descriptive statistics, Spearman's rank correlation coefficient).

\section{RESULTS}

In table 1 shows the quantitative indicators of this sample of students by years of study, by age, by gender. The mean values of the age of first and second year students and their standard deviations for men and women are presented.
Research has shown that women are mostly selected for vocational training in tourism. $60 \%$ of women and $40 \%$ of men study in the first year of vocational training. In the second year $67 \%$ of women and $33 \%$ of men are studying. For men, the average age at the first year of professional training at the university is 18 years 3 months, and for women - 18 years 2 months. In the second year of professional training, the average age for men is 20 years 1 month, and for women - 19 years 7 months.

\begin{tabular}{|c|c|c|c|c|c|c|}
\hline \multirow[t]{2}{*}{ gender } & \multirow{2}{*}{$\begin{array}{l}\text { in total } \\
\mathrm{N}=43\end{array}$} & \multicolumn{2}{|l|}{ year of study } & \multicolumn{3}{|c|}{ Age at the date of the test for motivation } \\
\hline & & & & & $\mathrm{M}$ & Std. Dev. \\
\hline \multirow[t]{2}{*}{ Men } & \multirow[t]{2}{*}{16} & first-year & 10 & $17-20$ & 18,3 & 0,42 \\
\hline & & second-year & 6 & $18-22$ & 20,1 & 1,16 \\
\hline \multirow[t]{2}{*}{ Women } & \multirow[t]{2}{*}{27} & first-year & 15 & $17-20$ & 18,2 & 0,38 \\
\hline & & second-year & 12 & $18-22$ & 19,7 & 0,76 \\
\hline
\end{tabular}

Table: 1. The demographic profile of the student's specialty "Tourism"

Table 2 presents the average values of the ranks of educational activities and their standard deviations for firstand second-year students. The analysis of the meanings and (std. dev.) showed that for the students of the first year the meaning of the "working" may be significant, and for the second-year students, the "professional" motives and the "obtaining a diploma" motive can be significant.

\begin{tabular}{|l|l|l|l|l|}
\hline \multirow{2}{*}{ Motives of educational and professional activity } & \multicolumn{2}{|l|}{ first-year, N=25 } & \multicolumn{2}{l|}{ second-year, N=18 } \\
\cline { 2 - 5 } & mean & std. dev. & mean & std. dev. \\
\hline obtaining a diploma & 8,6 & 2,08 & 7,4 & 2,54 \\
\hline material support & 10,0 & 4,73 & 11,4 & 3,76 \\
\hline legal aspects & 7,6 & 4,10 & 8,9 & 3,72 \\
\hline working & 7,3 & 5,04 & 8,6 & 4,30 \\
\hline approval of the others & 10,2 & 4,77 & 11,1 & 3,57 \\
\hline prestige of the university & 11,0 & 4,35 & 10,2 & 5,28 \\
\hline professional & 7,5 & 2,03 & 7,0 & 1,68 \\
\hline educational-cognitive & 9,0 & 2,64 & 9,4 & 2,31 \\
\hline
\end{tabular}

Table: 2. Descriptive statistics of the ranks of the significance of motives over the years of study at the students of the specialty "Tourism"

The results of one-factor dispersion analysis of the ranks of first and second year $(\mathrm{F}=7.56 ; \mathrm{P}<0.01)$. Also statistically the significance of the motives of teaching and professional significant differences between the students of the first and activities for students of the first and second year of the second year were obtained in the significance of the "material specialty Tourism are presented in Table 3. The results support" motive $(\mathrm{F}=5,05 ; \mathrm{P}<0,05)$ and the motive of the showed statistically significant differences in the significance "legal aspects" ( $F=5,09 ; \mathrm{P}<0,05)$. of the "obtaining a diploma" motive among the students of the

\begin{tabular}{|c|c|c|c|c|}
\hline \multirow[t]{2}{*}{ Motives of educational and professional activity } & \multicolumn{4}{|c|}{ first-year, $\mathrm{N}=25$; second-year, $\mathrm{N}=18$} \\
\hline & $\mathrm{F}$ & F crit & $\mathrm{P}$ & \\
\hline obtaining a diploma & 7,56 & 7,30 & 0,009 & $\mathrm{P}<0.01$ \\
\hline material support & 5,05 & 4,08 & 0,030 & $\mathrm{P}<0.05$ \\
\hline legal aspects & 5,09 & 4,08 & 0,030 & $\mathrm{P}<0.05$ \\
\hline working & 4,04 & 4,08 & 0,051 & \\
\hline approval of the others & 1,88 & 4,08 & 0,178 & \\
\hline prestige of the university & 1,61 & 4,08 & 0,212 & \\
\hline professional & 1,32 & 4,08 & 0,257 & \\
\hline educational-cognitive & 0,64 & 4,08 & 0,430 & \\
\hline
\end{tabular}

Table: 3. Results of one-factor dispersion analysis (ANOVA) of the rankings students' motives of the specialty "Tourism" the first and second year of study

In table 4 shows the average values of the ranks of the motives (women) and their standard deviations. Based on the analysis «professional», «educational-cognitive» and the motives «working», «obtaining a diploma», «prestige of the university», «approval of the others», «legal aspects», «material support» for students (men) and female students

of mean values and std. dev., 
The Professional Training Motives of Ukrainian Students on Specialty "Tourism" At Technical University: Gender Index

it has been determined that for students the motives and professional motives may be significant, and for professional

students, the "professional" motives may be significant.

\begin{tabular}{|l|l|l|l|l|}
\hline \multirow{2}{*}{ Motives of educational and professional activity } & Men, N=16 & Women, N=27 \\
\cline { 2 - 5 } & mean & std. dev. & mean & std. dev. \\
\hline obtaining a diploma & 8,7 & 2,33 & 7,8 & 2,31 \\
\hline material support & 10,6 & 4,16 & 10,6 & 4,70 \\
\hline legal aspects & 8,0 & 4,16 & 8,2 & 4,07 \\
\hline working & 7,1 & 5,54 & 8,3 & 5,24 \\
\hline approval of the others & 9,7 & 6,01 & 11,1 & 3,58 \\
\hline prestige of the university & 10,6 & 5,26 & 10,7 & 5,01 \\
\hline professional & 7,1 & 1,95 & 7,4 & 2,00 \\
\hline educational-cognitive & 9,4 & 2,57 & 9,0 & 2,42 \\
\hline
\end{tabular}

Table: 4. Descriptive statistics of gender differences ranks of significance motives in students the specialty "Tourism"

The study of gender features of the importance of educational and professional motives for students of the specialty "Tourism" was conducted. Table 5 presents the results of a one-factor dispersion analysis of the ranks of the significance of the motives of educational and professional activity for male and female students. The obtained data revealed statistically significant differences in the significance of the "approval of the others" motive $(\mathrm{F}=4.21$; $\mathrm{P}<0.05)$ between male and female students.

\begin{tabular}{|c|c|c|c|c|}
\hline \multirow[t]{2}{*}{ Motives of educational and professional activity } & \multicolumn{4}{|c|}{ Men, N=16; Women, N=27 } \\
\hline & $\mathrm{F}$ & F crit. & $\mathrm{P}$ & \\
\hline obtaining a diploma & 3,57 & 4,08 & 0,066 & \\
\hline material support & 0,01 & 4,08 & 0,921 & \\
\hline legal aspects & 0,12 & 4,08 & 0,730 & \\
\hline working & 2,77 & 4,08 & 0,103 & \\
\hline approval of the others & 4,21 & 4,08 & 0,047 & $\mathrm{P}<0.05$ \\
\hline prestige of the university & 0,05 & 4,08 & 0,824 & \\
\hline professional & 0,56 & 4,08 & 0,459 & \\
\hline educational-cognitive & 0,66 & 4,08 & 0,423 & \\
\hline
\end{tabular}

Table: 5. Results of one-factor dispersion analysis (ANOVA) of gender differences in the significance of the motives of students of the specialty "Tourism"

In table 6 shows the average learning success of students of specialized disciplines and practices and their standard deviations separately for men and women. The success of learning from such disciplines as: "geography of tourism", "tourist resources of Ukraine", "specialized tourism" and educational practice "introduction to specialty". Analysis of mean values showed that the average values of the success women have higher of all the specialized disciplines and practices. Standard deviations from the average values of the success in women are lower compared to men from all academic disciplines and practices.

\begin{tabular}{|l|l|l|l|l|}
\hline \multirow{2}{*}{ Educational disciplines and practices } & Men, N=16 & \multicolumn{2}{l|}{ Women, N=27 } \\
\cline { 2 - 5 } & mean & std. dev. & mean & std. dev. \\
\hline geography of tourism & 78,7 & 15,85 & 88,2 & 10,92 \\
\hline introduction to the specialty & 80,9 & 21,35 & 84,7 & 11,33 \\
\hline tourist resources of Ukraine & 76,0 & 17,93 & 84,1 & 10,88 \\
\hline specialized tourism & 76,8 & 10,15 & 87,1 & 12,59 \\
\hline
\end{tabular}

Table: 6. Descriptive statistics of gender differences in the success of studying students in the specialty "Tourism"

The results of the descriptive statistics of the source data and from the discipline "specialized tourism $(\mathrm{F}=114.44 ; \mathrm{P} \& \mathrm{lt}$; the results of the one-factor dispersion analysis (ANOVA) of the gender differences in the success of the studies in the first year of study are presented in Table 7 . The analysis of the results obtained revealed that the gender differences of the freshmen are statistically significant in the success of studying in the discipline "geography of tourism" (F = 152,51; $\mathrm{P}$ $<0.00001$ ), from the academic practice "introduction to the specialty" ( $\mathrm{F}=34,43 ; \mathrm{P}<0.00001)$, from the discipline "tourist resources of Ukraine" ( $\mathrm{F}=139,86 ; \mathrm{P}<0.00001)$, 


\begin{tabular}{|c|c|c|c|c|c|c|c|c|}
\hline \multirow{2}{*}{$\begin{array}{ll}\text { Educational } & \text { disciplines } \\
\text { and practices } & \end{array}$} & \multicolumn{2}{|c|}{ Man, $\mathrm{N}=10$} & \multicolumn{2}{|c|}{ Women, $\mathrm{N}=15$} & \multirow[t]{2}{*}{$\mathbf{F}$} & \multirow[t]{2}{*}{ F crit. } & \multirow[t]{2}{*}{$\mathbf{P}$} & \\
\hline & mean & std. dev. & mean & std. dev. & & & & \\
\hline geography of tourism & 71,7 & 7,97 & 89,0 & 14,22 & 152,51 & 31,66 & 0,00 & $\mathrm{P}<0.00001$ \\
\hline $\begin{array}{l}\text { introduction to the } \\
\text { specialty }\end{array}$ & 74,5 & 20,70 & 84,3 & 14,38 & 34,43 & 31,66 & 0,00 & $\mathrm{P}<0.00001$ \\
\hline $\begin{array}{lll}\text { tourist } & \text { resources } & \text { of } \\
\text { Ukraine } & & \end{array}$ & 69,0 & 8,24 & 85,1 & 12,90 & 139,86 & 31,66 & 0,00 & $\mathrm{P}<0.00001$ \\
\hline specialized tourism & 72,5 & 10,04 & 88,6 & 15,87 & 114,44 & 31,66 & 0,00 & $\mathrm{P}<0.00001$ \\
\hline
\end{tabular}

Table: 7. Descriptive statistics of the initial data and the results of a one-factor dispersion analysis of gender differences in the success of training in the students of the first year of studying the specialty "Tourism"

In table 8 presents the results of a one-factor dispersion analysis of the success of the training of students in specialized specialty disciplines and practices for men and women who are junior students of the specialty Tourism. A comparative analysis of gender differences in the success of students from academic disciplines "geography of tourism", "tourist resources of Ukraine", "specialized tourism" and "introduction to the specialty" was conducted. Gender differences in the success of training in specialized disciplines and educational practice are revealed:

- discipline "geography of tourism" ( $\mathrm{F}=71,76$; $\mathrm{P}<0.00001)$; - educational practice "introduction to the specialty" ( $\mathrm{F}=9$,

- discipline "tourist resources of Ukraine" $(\mathrm{F}=50,86$; $\mathrm{P}$ $<0.00001)$;

- discipline "specialized tourism (children, youth, religious)" ( $\mathrm{F}=90,15 ; \mathrm{P}<0.00001)$.

Thus, the results showed statistically significant gender differences in the success of the training of students of junior high school courses from all the specialized educational disciplines and practices studied. $69 ; \mathrm{P}<0,005)$;

\begin{tabular}{|c|c|c|c|c|}
\hline \multirow[t]{2}{*}{ Educational disciplines and practices } & \multicolumn{4}{|c|}{ Man, $N=16 ;$ Woman, $N=27$} \\
\hline & $\mathrm{F}$ & F crit. & $\mathrm{P}$ & \\
\hline geography of tourism & 71,76 & 25,36 & 0,000 & $\mathrm{P}<0.00001$ \\
\hline introduction to the specialty & 9,69 & 8,80 & 0,003 & $\mathrm{P}<0.005$ \\
\hline tourist resources of Ukraine & 50,86 & 25,36 & 0,000 & $\mathrm{P}<0.00001$ \\
\hline specialized tourism & 90,15 & 25,36 & 0,000 & $\mathrm{P}<0.00001$ \\
\hline
\end{tabular}

Table: 8. Results of one-factor dispersion analysis (ANOVA) of gender differences in the success of studying students of the specialty "Tourism"

In table 9 presents the significance of the motives of educational and professional activities for students, depending on the year of study. The analysis of the results showed that for the students of the first year the most significant are the following motives:

\begin{tabular}{|l|l|l|l|}
\hline \multirow{2}{*}{$\begin{array}{l}\text { Motives of educational and professional } \\
\text { activity }\end{array}$} & Total & first-year, N=25 & second-year, N=18 \\
\cline { 2 - 4 } & $\%$ & $\%$ & $\%$ \\
\hline working & 53 & 60 & 44 \\
\hline legal aspects & 47 & 52 & 39 \\
\hline professional & 47 & 44 & 50 \\
\hline material support & 28 & 40 & 11 \\
\hline educational-cognitive & 23 & 28 & 17 \\
\hline approval of the others & 21 & 28 & 11 \\
\hline obtaining a diploma & 35 & 24 & 50 \\
\hline prestige of the university & 23 & 20 & 28 \\
\hline
\end{tabular}

Table: 9. The significance of motives by the years education students specialty "Tourism

" educational and professional The insignificant motives of educational and professional
activity for students depending on the year of study are presented in Table 10. For the students of the first course, the following motives are the most insignificant: for $56 \%$ of
- for $60 \%$ of respondents - the motive "working",

- for $53 \%$ of respondents - the motive of the "legal aspects".

For students of the second year, the following motivations are the most significant: for $50 \%$ of respondents - the motive "obtaining a diploma" and "professional" motives.

respondents - the motive of the "prestige of the university", for $52 \%$ of respondents - the motive "approval of the others". For students, $60 \%$ of the second year, the most insignificant is the motive of "material support". 
The Professional Training Motives of Ukrainian Students on Specialty "Tourism" At Technical University: Gender Index

\begin{tabular}{|c|c|c|c|}
\hline \multirow{2}{*}{$\begin{array}{l}\text { Motives of educational and professional } \\
\text { activity }\end{array}$} & Total & first-year, $N=25$ & second-year, $\mathrm{N}=18$ \\
\hline & $\%$ & $\%$ & $\%$ \\
\hline working & 28 & 28 & 28 \\
\hline legal aspects & 23 & 16 & 33 \\
\hline professional & 0 & 0 & 0 \\
\hline material support & 53 & 48 & 61 \\
\hline educational-cognitive & 14 & 16 & 11 \\
\hline approval of the others & 49 & 52 & 44 \\
\hline obtaining a diploma & 9 & 12 & 6 \\
\hline prestige of the university & 51 & 56 & 44 \\
\hline
\end{tabular}

Table: 10. The insignificance motives over the years education in the students of the specialty "Tourism"

Gender characteristics of the significance of the motives of the educational and professional activity of junior students of the specialty "Tourism" are reflected in Figure 1. The motive of "material support" is significant for $63 \%$ of men and "professional" motives - for $50 \%$ of men, motives "obtaining a diploma" and "prestige of the university"- for $48 \%$ of women.

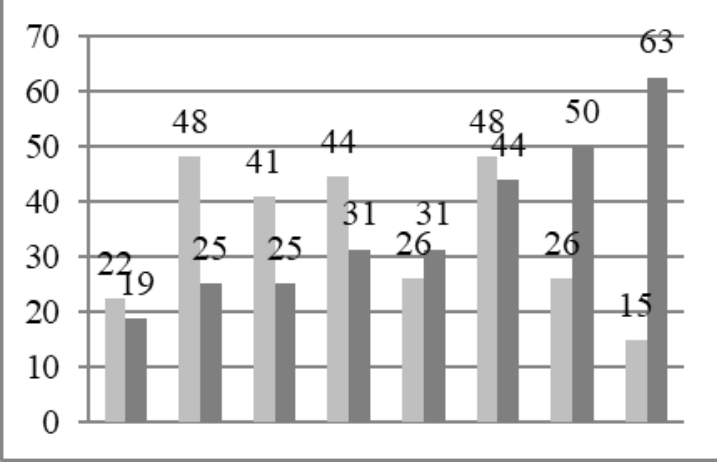

Fig. 1. Gender peculiarities of students' motives significance of the specialty "Tourism"

Figure 2 shows the gender characteristics of the insignificance motives of the educational and professional activities students of the first and second year. For $56 \%$ of men, there are insignificant "educational-cognitive" motives and for $50 \%$ of men the "working" motive; for $56 \%$ of women - "professional" motives and for 52\% of women - the motive "material support".

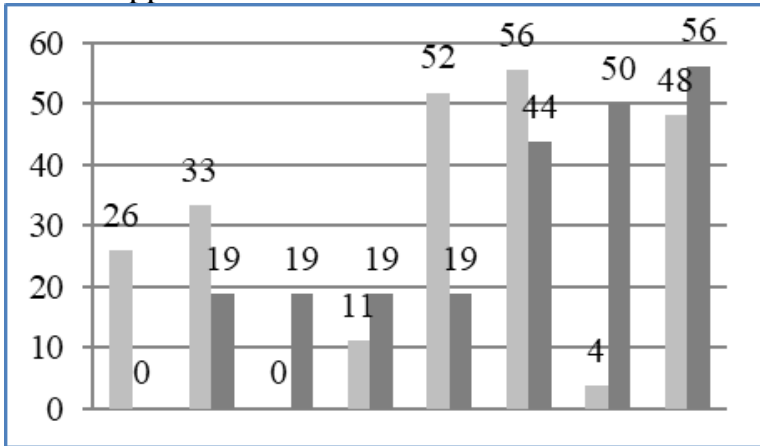

Fig. 2. Gender peculiarities of the insignificance of students' motives of the specialty "Tourism"

In table 11 presents the Spearman's rank correlation motives for educational and professional activity with indicators of success in the specialized specialization disciplines and practices of students in the first year of study. The analysis of correlations showed that the motives of educational-professional activity correlate with the success in specialized disciplines in the following way:

- the motive of "material support" with the indicators of "tourist resources of Ukraine" -0.37 , correlation is significant at the level $\mathrm{P}<0.05$;

\begin{tabular}{|c|c|c|c|c|c|c|c|c|}
\hline Rs & 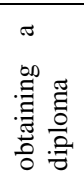 & 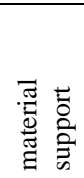 & 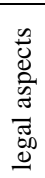 & 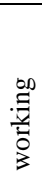 & 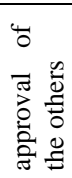 & 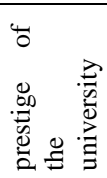 & 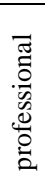 & 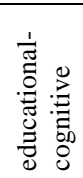 \\
\hline \multicolumn{9}{|l|}{ geography of tourism } \\
\hline \multicolumn{9}{|l|}{ introduction to the specialty } \\
\hline tourist resources of Ukraine & & $-0,37^{*}$ & & & & & & \\
\hline \multicolumn{9}{|l|}{ specialized tourism } \\
\hline history of tourism & $-0,37^{*}$ & & & & & & & \\
\hline $\begin{array}{l}\text { recreation and tourism states of the } \\
\text { world }\end{array}$ & $-0,42^{* *}$ & $-0,42^{* *}$ & & & & & & $0,35^{*}$ \\
\hline
\end{tabular}

Table: 11. Relationship of the motives with the success training courses and practices of the students the first year of studying the specialty

"Tourism"

$*$ the correlation is significant at the level $\mathrm{P}<0.05, * *$ the correlation is significant at the level $\mathrm{P}<0.025$

- the motive "obtaining a diploma" with indicators of success "history of tourism" -0.37. The correlation is significant at the level $\mathrm{P}<0,05$;
- the motive «obtaining a diploma» and the motive «material support» with indicators of success «recreation and tourism states of the world» $-0,42$, the correlation is significant at the level $\mathrm{P}<0,025$; 
- "educational-professional" motives with indicators of success "recreation and tourism states of the world"-0,35, correlation is significant at the level $\mathrm{P}<0,05$. Table $\quad 12$ shows the results of the Spearman's rank correlation motives of educational and professional activity with the indicators success in the specialized specialization disciplines and practices of the second-year students. The analysis of correlations showed that the motives of educational-professional activity correlate with the success in specialized disciplines:

- the motive "working" -0.40 and "professional" motives 0.42 with indicators of success in production practice, the correlation is significant at the level $\mathrm{P}<0,05$; - the motive of the "legal aspects" is 0.43 , the correlation is significant at the level $\mathrm{P}<0,05$ and the motive "working" - 0,57 , the correlation is significant at the level $\mathrm{P}<0,01$ with indicators of success "Information technologies in tourism"; - "working" motif -0.44 with indicators of success "activities of a travel agency and organization of tourist business", the correlation is significant at the level $\mathrm{P}<0,05$;

- the motive of the "legal aspects" is 0.43 , the correlation is significant at the level $\mathrm{P}<0,05$ and the motive "working" $-0,65$, the correlation is significant at the level $\mathrm{P}<0,0025$ with indicators of success "organization of tourist trips".

\begin{tabular}{|c|c|c|c|c|c|c|c|c|}
\hline Rs & 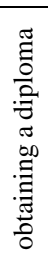 & 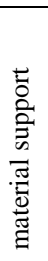 & 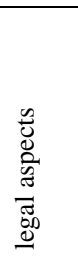 & 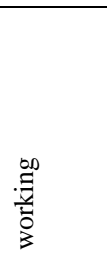 & 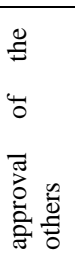 & 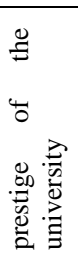 & 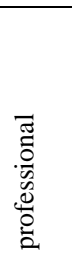 & 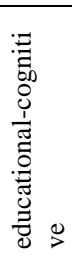 \\
\hline internship & & & & $-0,40^{*}$ & & & $0,42^{*}$ & \\
\hline information technology in tourism & & & $0,43^{*}$ & $-0,57^{* * *}$ & & & & \\
\hline \multicolumn{9}{|l|}{ tourist region studies } \\
\hline $\begin{array}{l}\text { activities of a travel agency and } \\
\text { organization of tourist business }\end{array}$ & & & & $-0,44^{*}$ & & & & \\
\hline organization of tourist trips & & & $0,43^{*}$ & $-0,65^{* * * * *}$ & & & & \\
\hline
\end{tabular}

Table: 12. Relationship of the motives with the success of the training courses and practices of students of the second year of studying the specialty "Tourism". * the correlation is significant at the level $P<0,05 * *$, the correlation is significant at the level $P<0,025$, *** the correlation is significant at the level $P<0,01$, **** the correlation is significant at the level $P<0,0025$

The conducted research showed that the most important motives of professional training for students of the first year of the specialty "Tourism" is the motive "working", and for students of the second year there are "professional" motives and the motive "obtaining a diploma". The statistically significant differences in the significance of the motives "obtaining a diploma", "material support" and "legal aspects" for the students of the first and second year are determined. The data obtained revealed statistically significant gender differences in the significance of the "approval of the others" motive for Ukrainian students. Also, statistically significant gender differences in the success of the first-year students' training in all specialized disciplines and practices have been identified. The insignificance of the motives of educational and professional activity for students depending on the year of study is found out: for the students of the first course the most insignificant are the motive of the "prestige of the university" and the motive "approval of the others", for the second year

\section{CONCLUSIONS}

In the field of NTM education, the studies were aimed at ascertaining the peculiarities of the motivation or the preferences of students regarding the choice of programs for professional training. Most studies have studied both national characteristics and intercultural differences in motivation and career advancements. This study determined the relationship between the motives and the success of the professional training of Ukrainian students over the years of study, their gender characteristics. The results of this study are of interest to various stakeholders in NTM education, for potential NTM students, NTM teachers, for administrative staff who develop NTM curricula. students the most insignificant is the motive of "material support". It was stated that the motives of educational and professional activity of the students of the first and second year of study are related to the success in specialized disciplines. Such motives for the students of the first year of study are the motive "obtaining a diploma" and the motive "material support", for students of the second year of study there is the motive "working". The motive "working" for students of the second year of study is related to the success of the practice of business, acquiring practical skills.

Research of features of gender differences of students in learning motivation by specialty showed that the motif of "material support" and "professional" motives are significant for men, but the motives are "obtaining a diploma" and "prestige of the university" is important for women. For men are insignificant "educational-cognitive" motives and the motive "working" and for women are insignificant "professional" motives and the motive of "material support". The results of this study contain new information, but it cannot be said that they will be characteristic of all educational institutions and all students of NTM education in Ukraine. The obtained conclusions are the basis for representations about the influence of motives on the success of professional training of students in the specialty "Tourism" and their use in further research. The methodology used in this study can be adapted to use the study of the motives of students of other specialties, for different levels and training programs. 


\section{REFERENCES}

1. Antonova, N.A. (2001). Value orientations in the structure of the student's personality: monograph. Slavyansk.

2. Babkina, O. (2006). Problems of Improving the Quality of Higher Education in Ukraine in the Context of Bologna Reforms.Education and Management. 9(1) 91-94.

3. Brunets, B.R. (2012). The experience of training hospitality and tourism personnel on the example of the Netherlands.Geography and Tourism. $25-31$.

4. Burego, O.M. (2009). Theoretical principles of management of the quality system of higher education. Modern social problems in the measurement of sociology of management: a collection of scientific works of the DSUM. 10(115). Donetsk. 327-333.

5. Lebedev, O.Ye. (2007). What is the quality of education?. Higher education today]. 2. 34-39.

6. Mazak, A.V. (2005). Management of the educational branch in the conditions of formation of civil society in Ukraine: regional aspect. (PhD thesis, NAPA under the President of Ukraine).

7. Matros, D.Sh., Polev, D.M., \& Mel'nykova, N.N. (2001). Management of the education quality based on information technology and educational monitoring]. Moscow.

8. Shinkaruk, V. (2007). Main directions of higher education structure modernization of Ukraine. High school. 5. 3-16.

9. Knodel, L.V. (2007). The theory and practice of training specialists in the field of tourism in member countries of the World Tourism Organization. (PhD thesis, Ternopil national Pedagogical University Untitled Volodymyr Hnatyuk).

10. Garbar, G.A. (2018). World experience of personnel training in the hospitality field. The state and prospects of science development in Ukraine: a collection of abstracts of the IV All-Ukrainian scientific and practical conference. (p. 43-48). Mykolayiv.

11. Fedorchenko, V.K., Fomenko, N.A., Skrypnyk, M.I., \& Tsekhmystrova, G.S. (2004). Pedagogy of tourism. Kiev.

12. Liubchuk, O.K. (2012). The problem of formation of educational and professional motivation of future managers as a psychological factor for improving the quality of professional training for postindustrial production. Problems of general and pedagogical psychology. XIV(6) $259-264$

13. Liubchuk, O.K. (2005). Study of "Self-identity" of schoolboys and students as subjects of learning activity. Scientific works collection of the Institute of Psychology untitled G.S. Kostyuk APS of Ukraine. Kiev, 7(5). 219-228.

14. Lee, M. J., Kim, S. S., \& Lo, A. (2008). Perceptions of hospitality and tourism students towards study motivations and preferences: a study of Hong Kong students. Journal of Hospitality, Leisure, Sport and Tourism Education. 7(2), 45 - 58.

15. Cesário, F., Portugal, M. N., Rodrigues, B., \& Correia, A. (2017). Motivation for a Career in Hotel and Tourism Industry: a self-determination approach. 7th ATMC - Advances in Tourism Marketing Conference, "The Art of Living Together", Casablanca, Marrocos, 6-9 Set. Retrieved from

16. https://www.researchgate.net/publication/319837794_Motivation_fo r_a_Career_in_the_Hotel_and_Tourism_Industry_A_Self-Determinat ion_Approach.

17. Mohammad, B. A. A., \& Alsaleh, H. T. (2013). Motivation of students to study tourism hospitality programs. International Journal of Asian Social Science. 3(7), 1637-1647. Retrieved from

18. http://www.aessweb.com/pdf-files/ijass\%203(7),1637-1647.pdf.

19. Theresa, A.A. E., \& Agbotse, G. K. (2013). Student Motivation and Preference of Studying Hospitality and Tourism Management Programmes in Polytechnics: A Study of Hospitality and Tourism Management Students-Ho Polytechnic. European Journal of Business and Management. 5(1), $142-153$.

20. http://iiste.org/Journals/index.php/EJBM/article/download/3915/3973

21. .Kim, S., Jung, J., \& Wang, K-C. (2016). Hospitality and tourism management students' study and career preferences: Comparison of three Asian regional groups. Journal of Hospitality, Leisure, Sport \& Tourism Education. 19, 66-84. Retrieved from

22. .http://web.ntnu.edu.tw/ gordonwang/2016\%20index $\% 20$ files $\% 20$ fil ms/Hospitality $\% 20$ and $\% 20$ tourism $\% 20$ management $\% 20$ students $\% 2$ 0study $\% 20$ and $\% 20$ career $\% 20$ preferences $\% 20$ Comparison $\% 20$ of $\% 20$ three\%20Asian\%20regional\%20groups.pdf.

23. Lee, M. J., Olds, D. A., \& Lee, C. (2010). Why Students Choose a Hospitality and Tourism Program: A Pilot Study of U.S. Undergraduate Students. Journal of Hospitality \& Tourism Education. 22(3), 20-26 | Published online: 29 May 2013. Retrieved from
24. .https://www.researchgate.net/publication/232045462_Why_Students _Choose_a_Hospitality_and_Tourism_Program_A_Pilot_Study_of_ US_Undergraduate_Students.

\section{AUTHORS PROFILE}

Lyubchuk, O.K., Professor, DPA, PhD., Head of Department of tourism, State Higher Educational Institution "Pryazovskyi State Technical University", Mariupol, Ukraine

Kocharyan O. S., Doctor of Psychological Sciences, Professor. V. N. Karazin Kharkiv National University, Head of the Department of Psychological Counseling and Psychotherapy. Ukraine.

Barinova N.V. , PhD., Department of Psychological Counseling and Psychotherapy, V.N. Karazin Kharkiv National University, Kharkiv, Ukraine

Lunov V.Ye., PhD., Professor (Associate), Bogomolets National Medical University, Ukraine.

Koval I.A., PhD., MD, Professor (Associate), Bogomolets National Medical University, Ukraine.

Onufriieva L., PhD., Professor (Associate), Kamianets-Podilskyi National Ivan Ohiienko University, Kamianets-Podilskyi, Ukraine

Koval A.Sh., PhD., Associate Professor of Department of Social and Applied Psychology, Odessa I.I.Mechnikov National University, Ukraine 